\title{
Principal Strategy in Partnership Development
}

\section{Sastramayani}

Faculty of Teacher Training and Education, Universitas Lakidende Email: sastramayani.unilaki@gmail.com

\begin{abstract}
This article aims to provide a conceptual overview of the principal's strategy in partnership development. The aspects studied are: 1) various dimensions of strategy; 2) The roles of school principals; and 3) Partnership development. The method used is a literature review, where the authors synthesize and develop various concepts and findings related to the principal's strategy in developing partnerships. The results of the study show that: first, strategy is a prerequisite in carrying out leadership roles. A reliable principal will be seen in his ability to read environmental conditions, internal and external, to formulate a grand design for school development. The concrete form is the formulation of the school's vision, mission, goals, and programs. Second, the roles of principals are increasingly complex in the midst of very fast environmental changes, as well as very tight competition between schools. Not only managerial roles, more than that the principal must appear as a leader who makes a difference. Third, partnership development is a deeper meaning of school quality. That schools do not exist in an empty space, but are directly connected to the community and the world of work as users of educational services. This article suggests the importance of increasing knowledge about strategy for school principals, followed up with technical skills in the strategy stages.
\end{abstract}

\section{Keywords: Strategy, School Management, Partnership, Quality}




\title{
Strategi Kepala Sekolah dalam Pengembangan Kemitraan
}

\section{Sastramayani}

Fakultas Keguruan dan Ilmu Pendidikan, Universitas Lakidende Email: sastramayani.unilaki@gmail.com

\begin{abstract}
Abstrak
Artikel ini bertujuan memberikan gambaran konseptual tentang strategi kepala sekolah dalam pengembangan kemitraan. Aspek-aspek yang didalami adalah: 1) berbagai dimensi tentang strategi; 2) Peran-peran kepala sekolah; dan 3) Pengembangan kemitraan. Metode yang digunakan adalah literature review, dimana penulis melakukan sintesis dan pengembangan terhadap berbagai konsep dan temuan terkait strategi kepala sekolah dalam pengembangan kemitraan. Hasil kajian menunjukkan bahwa : pertama, Strategi merupakan prasyarat dalam melaksanakan peranperan kepemimpinan. Kepala sekolah yang handal akan terlihat pada kemampuannya dalam membaca kondisi lingkungan, internal dan eksternal, untuk merumuskan desain besar pengembangan sekolah. Bentuk konkritnya adalah pada rumusan visi, misi, tujuan, dan program sekolah. Kedua, Peran-peran kepala sekolah semakin kompleks di tengah perubahan lingkungan yang sangat cepat, juga kompetisi antar sekolah yang sangat ketat. Tidak hanya peran-peran manajerial, lebih dari itu kepala sekolah harus tampil sebagai pemimpin yang membuat perbedaan. Ketiga, pengembangan kemitraan adalah pemaknaan lebih mendalam tentang kualitas sekolah. Bahwa sekolah tidak hadir pada ruang kosong, tetapi terhubung langsung dengan masyarakat dan dunia kerja sebagai pengguna jasa pendidikan. Artikel ini menyarankan penting peningkatan pengetahuan tentang strategi bagi kepala sekolah, ditindaklanjuti dengan keterampilan teknis dalam tahap-tahap strategi.
\end{abstract}

Kata Kunci: Strategi, Pengelolaan Sekolah, Kemitraan, Mutu 


\section{Introduction}

Strategy helps organizations leave the past behind, survive in the present, and orientate themselves into the future (Feurer \& Chaharbaghi, 1995). Using strategy means preparing the organization to be competitive, at any time (Singh at al, 2008). Strategy is the key to the success of an organization in achieving its goals. Without a strategy, the program will not run. Strategy is the first step that a leader must have in achieving goals. No matter how great a leader, if he doesn't have the right strategy, the program will be meaningless and the goals will not be realized. Leadership does not only rely on his own abilities but he must also have a strategy in leading. Strategy binds all parts of the organization into one, so that the strategy covers all important aspects of an organization, the strategy is integrated from all parts of the plan that must be in harmony with each other and fit. Therefore, determining strategy requires a level of commitment from an organization, where the organizational team is responsible for advancing the strategy that refers to the final result or goal (Yulmawati, 2016). The results show that the commitment of organizational members is very important in the implementation of the organization's overall strategy (Kohtamäki at.al, 2012).

The results or goals to be achieved in the future are related to the organization's social responsibility (Hanke \& Stark, 2009). So, not only on internal issues, but also includes connectedness with the community. It is precisely in this relationship that schools will achieve a high competitive level, namely quality schools. It can be said that strategy is an indicator of school quality, which is manifested in the strategic plan document dokumen (Syahrul at.al, 2017).

In this regard, the principal is one of the most important points in carrying out strategies in educational organizations. The leadership quality of the principal greatly determines the success of the institution he leads, including educational institutions. Because successful leadership is able to manage the institution it leads, is able to anticipate changes, is able to correct deficiencies and weaknesses and is able to bring the institution it leads to the goals set. In this regard, the leader is the key to success for the organization (Kartono, 2010). In the era of competition between regions such as the Asean Economic Community (AE), the principal's strategy is needed to improve the quality of education in order to adapt to the atmosphere (Tobari \& Asvio, 2018). 
In improving the quality of schools, principals should pay attention to the strategies to be used, the strategies used include the roles and duties of the principal, namely the principal must be able to become an educator, manager, administrator, supervisor, leader, innovator and motivator (Mendiknas, 2010). The competence of the principal's obligation to carry out his duties and functions optimally is that the principal must have future insight (vision) and know what to do (mission) and understand what methods will be taken (strategy), have the ability to coordinate and harmonize resources. limited resources that exist to meet the needs of schools which are generally not limited, have the ability to make decisions, have the ability to mobilize existing resources to achieve goals and are able to inspire their subordinates to do things that are important to school goals. (Kompri, 2015). The results show that the principal has a very complex role, such as improving the quality of education (Sakinah \& Ali, 2019), increased self-awareness (Sholekah \& Mahmudah, 2020), maximizing the use of infrastructure and the role of teachers in improving the quality of learning (Suliah \& Arafat, 2019).

The explanation above is related to the internal roles of the principal. What about external roles? The results of the study show that very fast progress requires schools to be connected to the outside world. Therefore, the partnership must be on the principal's agenda. In the case of vocational education, for example, the role of the principal is very important in the revitalization process proses (Akhyak at.al, 2018). Adoption of the latest technology in school development requires partnerships, spearheaded by principals (Wong \& Daud, 2017).

Figure 1. Flow of Thought

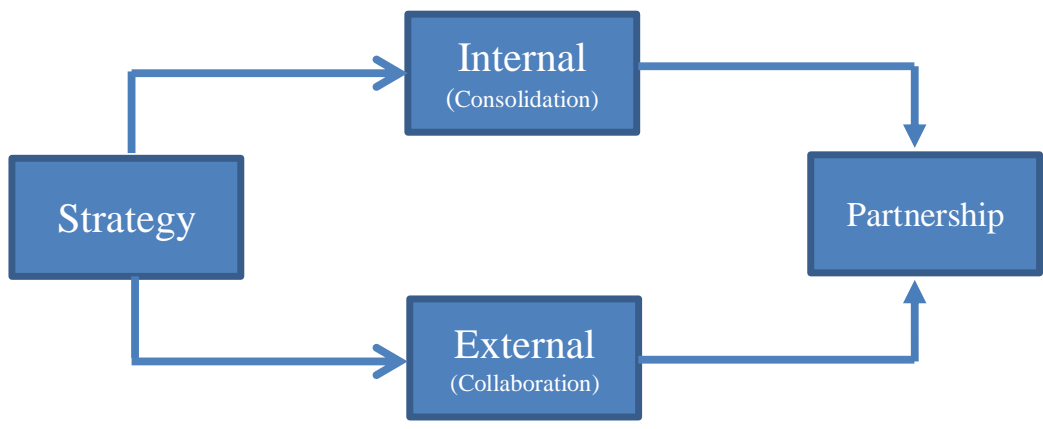


The strategic roles above can work properly if the principal has a high quality attitude towards the task. Various knowledge about school management may have been understood by the principal, but not necessarily in line with the commitment to implement it. This is a mental and moral aspect in carrying out the duties of the principal (Nur, 2020). This commitment is increasingly important in the midst of very fast developments that cause uncertainty (Syahrul, 2015), including when faced with force majeure conditions (Badarwan, 2021), and invisible competition (Syahrul, 2019), So it requires the presence of a leader figure who is able to stand firmly in times of crisis (Badarwan, 2020).

\section{Method}

The method used in this article is a literature review, where the author conducts an in-depth and critical evaluation of previous research (Shuttleworth, 2009). Several forms of previous research are: scientific journal articles, articles from conferences (proceedings), Theses and Dissertations, Research Reports, and textbooks. Several ways to do this are: look for similarities, look for dissimilarities (contrast), provide views (criticize), compare, and summarize. The author finally draws a conceptual conclusion regarding the principal's leadership in partnership development.

\section{Findings and Discussion}

\section{A. Strategy Definition}

Mintzberg defines strategy in several aspects, namely: Strategy as a perspective, Strategy as a position, Strategy as planning, Strategy as a pattern of activity, and Strategy as a "deception" (ploy), which is a secret trick (Mintzberg, 1978). As a perspective, where the strategy in shaping the mission, the mission describes the perspective to all activities. As a plan, in terms of strategies to determine learning performance goals. As a pattern of activities, where in the strategy a pattern is formed, namely feedback and adjustments (Rohim, 2019).

Johnson and Scholes view strategy as the long-term direction and reach of an organization; that achieves organizational excellence through configuring its resources in a challenging environment, to meet the various needs and expectations of interested parties (Walling, 2008). Meanwhile, Winardi sees strategy as a pattern of targets, goals and objectives and the main policies and plans to achieve these goals. 
The concept focuses more on the leadership's efforts in setting goals that must be achieved by the organization through an accurate, mature and systematic plan. Planning in this case is a pattern of certain policies in managing the organization towards the goals that have been set (Winardi, 2012).

It can be concluded that the strategy is a means used to obtain success or success in achieving the ultimate goal or goal. However, it is not just a plan, the strategy is also a design for the development of educational institutions as a guide in the implementation of achieving goals.

Figure 2. Dimensions of Mintzberg's Strategy

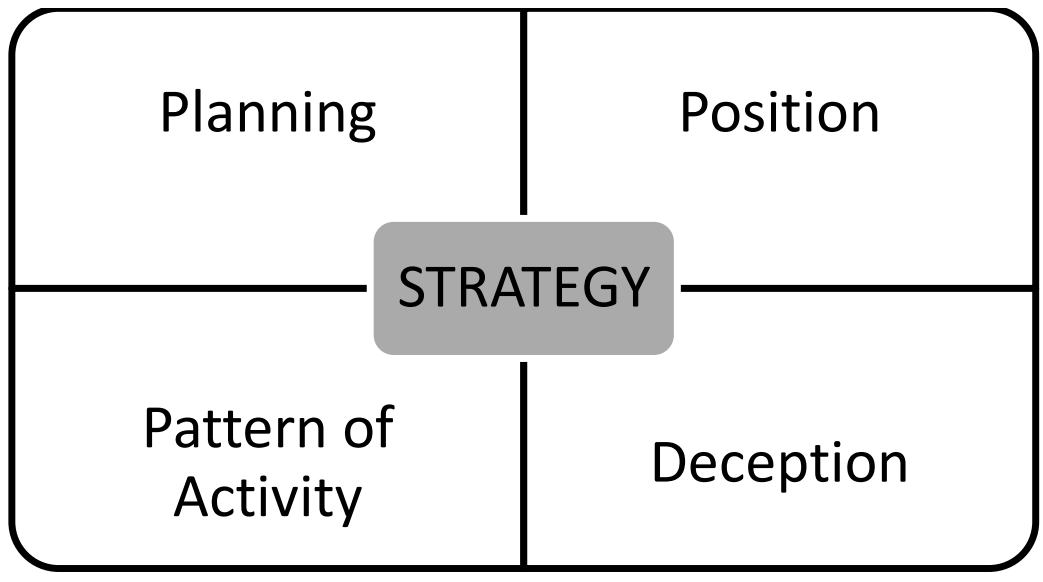

Figure 3. Strategies from different perspectives

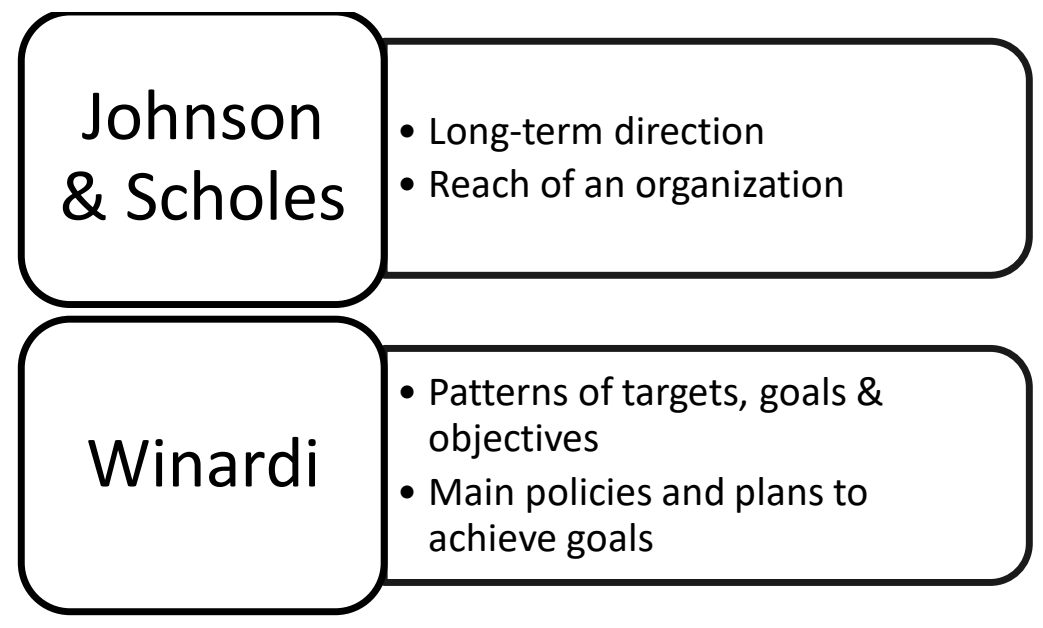




\section{B. Strategy Stages}

In principle, the strategy is divided into three stages, namely: 1) Strategy Formulation; 2) Strategy Implementation; and 3) Strategy Evaluation (Eisner at.al, 2016).

\section{B1. Strategy Formulation}

Strategy formulation is the development of long-term mission and goals, identifying opportunities and threats from outside as well as strengths and weaknesses of educational institutions, developing alternative strategies and determining appropriate strategies to be adapted. The steps of strategy formulation according to Sharplin are: (a) Establishing the mission of an educational institution, especially the development of the quality of educators; (b) Conducting the external environment of educational institutions regarding obstacles and incentives in improving the quality of educators in accordance with the capabilities of educational institutions; (c) Determine the direction and targets of educational institutions, especially the quality of educators to be achieved; (d) Determine the strategy to be used (Sagala, 2007).

\section{B2. Strategy Implementation}

Strategy implementation is the act of implementing a strategy that has been compiled into various optimal resource allocations. In the implementation of strategy implementation using information on strategy formulation to assist in the establishment of performance objectives, allocation, and priority of resources. Strategy implementation includes determining annual operational targets, educational institution policies, motivating educators and allocating resources so that the established strategy can be implemented (Akdon, 2007).

\section{B3. Strategy Evaluation}

Strategic evaluation or control includes efforts to monitor all the results of the formulation and implementation of strategies including measuring the performance of individuals and educational institutions and taking corrective steps if needed. Strategic control and evaluation need to be carried out for institutions in developing the quality of educators for several reasons, the more complicated and complex the quality of education that must be mastered will require a better control or control, and the more decentralized the power and authority of managers (heads of educational institutions) requires a a tool to determine the activities and performance of subordinates. 
Figure 4. Strategy Stages

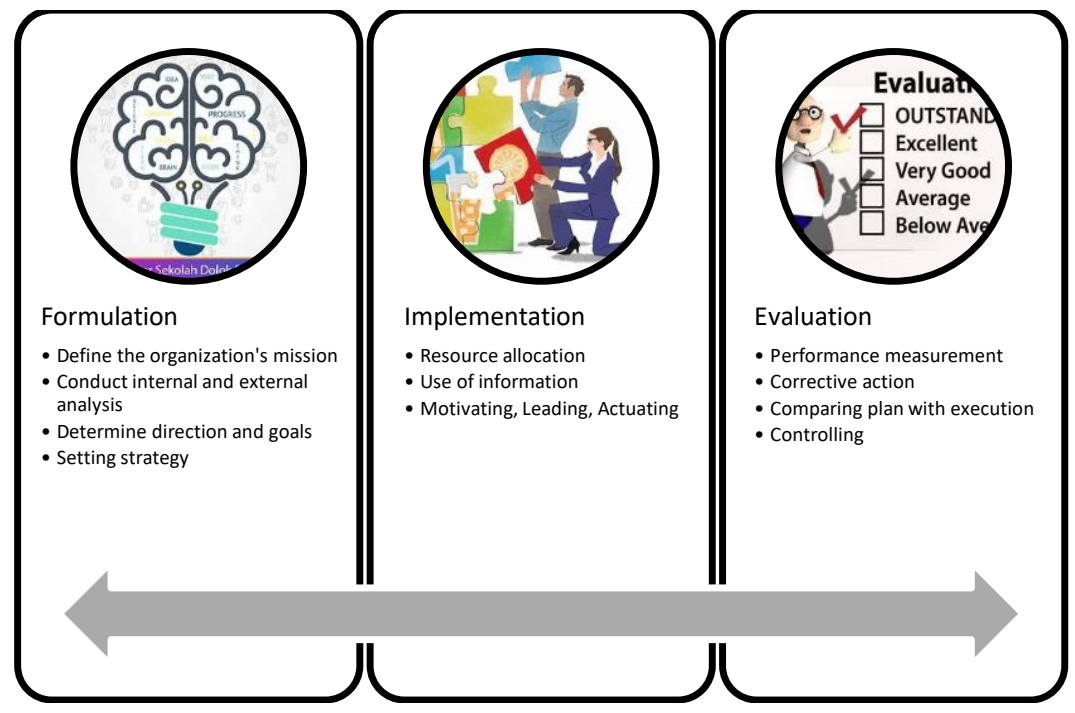

\section{Description of the Principal}

The principal as a leader, must have a strong personality, understand the circumstances and conditions of the school community, have short and long term programs, and be visionary, able to make the right and wise decisions and be able to communicate with all school members well (Bedanta, 2020). Leaders are not confined to an organizational structure, but rather create a difference and innovate (Syahrul, 2015). The ability to manage human resources is very important, because humans are the basis and orientation of organizational activities (Mukhtar \& Akbar, 2019).

The principal is one of the components of education that has the most role in improving the quality of education. As stated in article 12 paragraph 1 PP 28 of 1990 that: "the principal is responsible for the implementation of educational activities, school administration, coaching other educational staff, and the utilization and maintenance of facilities and infrastructure" (Mulyasa, 2007).

According to Daryanto, the principal is a school personnel who is responsible for all school activities, has the authority and responsibility to organize all educational activities in the school environment he leads on the basis of Pancasila which aims to increase devotion to God Almighty, improve intelligence and skills. , enhance 
character, strengthen personality, strengthen the spirit of nationalism and love for the homeland (Daryanto, 2010).

Furthermore, according to De Roche in Wahyudi that "The principal as an educational leader must have the ability, among others: to have leadership qualities, have high expectations of the school, be able to utilize school resources, and be professional in their field of duty" (Wahyudi, 2009).

Principals are successful if they understand the existence of the school as a complex and unique organization, and are able to carry out the role of the principal as someone who is given the responsibility to lead the school. As in a hadith explained, the Prophet SAW said: "Each of you is a leader and is responsible for everyone who is led and he is responsible for his people (Mahalli \& Rodli, 2004).

How important is the role of the principal in moving school life to achieve its goals. The principal must act as a central force that is the driving force of school life. Principals must also understand their duties and functions for the success of the school, and have concern for students, teachers, staff, and others involved in the school. provide impetus to spur and stand in front of progress and inspire schools in achieving goals. If a principal wants to succeed in mobilizing teachers, staff, and students to behave in achieving school goals, then the principal must avoid coercive attitudes and actions or act harshly against teachers, staff, and students. This is explained in QS. Al-Imran verse 159: So it is because of the mercy of Allah that you treat them gently. If you are hard and have a rough heart, they will certainly distance themselves from those around you (Depag RI, 2010).

On the other hand, the principal must be able to take action that gives birth to a willingness to work with enthusiasm and confidence towards teachers, staff and students in a persuasive manner, which means trying to make teachers, staff and students believe that what they are doing is right.

Principal leadership is one of the manifestations of national leadership, namely Pancasila leadership, a potential or strength that is able to empower all community and environmental resources inspired by Pancasila to achieve national goals in certain situations. Leadership is the process of influencing the activities of a person or group of people to achieve common goals in certain situations (Dharma, 2003). The key element is the influence that a person has and in turn the 
effect that influence has on the person to be influenced. A definition contains a meaning or values that can be developed further, so that from a definition a clear and comprehensive understanding of something can be obtained. One of the various definitions of leadership, suggests: "Leadership is interpersonal influence exercised in a situation, and directed, through the communication process, toward the attainment of a specified goal or goals"(Wahjosumidjo, 2005). Principal leadership is successful if they understand the existence of the school as a complex and unique organization, and are able to carry out the principal's role as someone who is given the responsibility to lead the school. Judging from the approach, there are three main types of principal leadership, namely "authoritarian leadership, laissez faire leadership and democratic leadership".

Democratic leadership, the leader believes that his role is to encourage, guide, gather, all the strengths of the group to the fullest and cooperate with the group in order to achieve common goals. $\mathrm{He}$ felt compelled to move the group towards the achievement of goals. Democratic leaders recognize that the strength of the group is the sum total of the strengths of its members. In other words, if he wants to improve the quality of his group, he will improve the quality of each member of his group. Therefore, in democratic leadership the main principle is to involve everyone in the process of setting and determining strategies in an effort to achieve common goals.

\section{C1. Duties and Functions of the Principal}

A school principal "has duties and responsibilities to superiors, to fellow principals or related environments and to their subordinates" (Wahyosumidjo, 2005:87). A principal has a superior, namely a direct supervisor and a higher superior. Because his position is tied to his superiors or as subordinates, a school principal must be loyal and carry out what is outlined by his superiors, the principal is also obliged to consult or provide reports regarding the implementation of the tasks that are his responsibility. Fellow school principals are required to maintain good cooperative relationships with other school principals and the environment, both with relevant agencies and community leaders. The principal's subordinates are obliged to create the best possible relationship with teachers, staff and students because the essence of leadership is following.

The acceptance of school principals towards innovations in the field of education administration is the main key to the acceptance of 
teachers and school staff in general, including students, to innovations that will be implemented in schools. This means that principals who are competent and have an innovative spirit are the main keys to whether or not the innovation is accepted by teachers, students, school administrators, as well as the key to the success of curriculum innovation in schools (Danim, 2002:146).

The principal's duties and functions include: 1) as an educator; 2) as manager; 3) as administrator; 4) as a supervisor; 5) as a leader; 6) as an innovator; and 7) as a motivator.

As an educator, the principal must have the right strategy to improve the competence of the education staff in his school. Creating a conducive school climate, providing advice to school residents, providing encouragement to all educational staff, and implementing interesting learning models, such as team teaching, moving classes, and holding acceleration programs for students who are above normal (Mulyasa, 200:99107). As educators, school principals must be able to instill, promote and improve four kinds of values, namely: 1) Mental, matters relating to inner attitudes and human character; 2) Moral, matters relating to good and bad teachings regarding actions, attitudes and obligations or morals which are defined as morals, character and decency; 3) Physical, matters relating to physical condition or body, health and human appearance outwardly; and 4) Artistic, matters relating to human sensitivity to art and beauty.

As a manager, the principal must be able to plan, organize, implement, lead and control the efforts of members of the organization and utilize all organizational resources in order to achieve the goals that have been set. It is said to be a process, because all managers with the dexterity and skills they have and utilize various interrelated activities to achieve goals. With good managerial skills, principals will be able to anticipate changes, understand and cope with situations, accommodate and reorient.

The principal as an administrator has a very close relationship with various administrative management activities that are in the nature of recording, compiling and documenting all school programs. Specifically, school principals must have the ability to manage facilities and infrastructure administration, manage personnel administration, manage facilities and infrastructure administration, manage archive administration, and manage financial administration. 
These activities need to be carried out effectively and efficiently in order to support school productivity.

As a supervisor, the principal conducts coaching that is planned to help teachers and school staff. The function of supervision or supervision in education is not just a control to see whether all activities have been carried out in accordance with the plans or programs that have been outlined, but more than that. Supervision includes determining the conditions or requirements for material capable personnel needed to create an effective teaching and learning situation and efforts to meet those requirements (Purwanto, 2006:76). As a person in charge of fostering his institution in order to successfully achieve the educational goals that have been determined, he must be able to direct and coordinate all activities. Such a task is none other than the task of supervision (Suryosubroto, 2004:183).

Figure 5. Principal's Duties

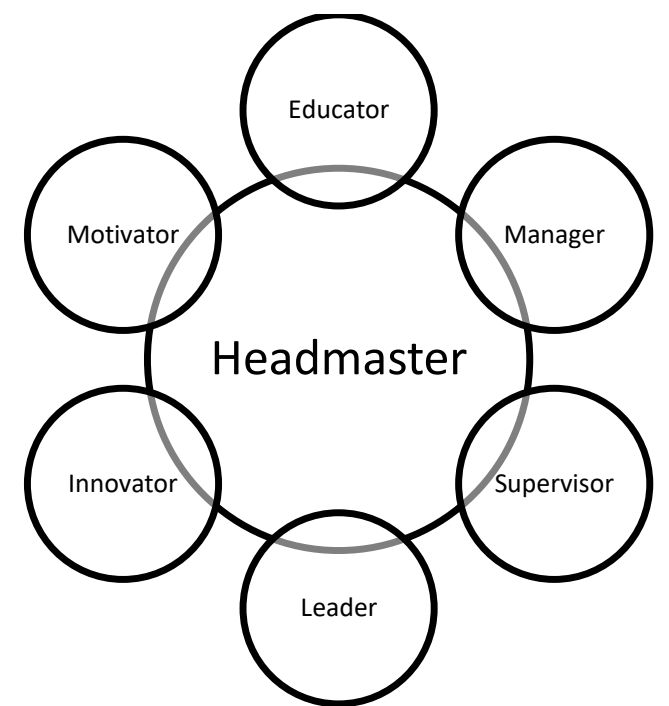

Based on the description above, what is meant by the principal's duties are the results achieved by the school as a form of leadership in leading the school. A good principal is a quality principal. The quality in question is the principal who is able to bring and utilize all the potential that exists for the progress of the school, as well as the principal who really has sufficient educational background and experience and can solve the problems faced in school properly.

The rapid development of information and communication technology has become a challenge for school principals to carry out 
various innovations. The industrial era 4.0 requires IT-based school management by making maximum use of the internet network, for example pioneering school websites (Laugi, 2020). Currently, educational institutions have developed websites as information systems, which present various school data (Laugi, 2018). In fact, it has specifically been used as a tool for managerial supervision (Syahrul at.al, 2019), and data mining to measure employee performance (Akib at.al, 2020).

\section{Partnership Development \\ D1. Definition of Partnership}

Partnership also means partnership. According to the guidelines, the partnership program development is a collaboration between the center and the regions by empowering each other's potential to carry out educational assessments and developments, especially the development of the competence of educators and education personnel in the regions. From this understanding, there is the essence of partnership in the form of cooperation between related parties in realizing the study and development of education. Partnership is a form of building a relationship or relationship. Jamal emphasized that the more successful relationships are built, the better for the institution because it will expand access and opportunities for growth.

The American Heitage Dictionary defines partnership as a relationship between individuals or groups that is characterized by mutual cooperation and responsibility, as for the achievement of a specified goal. Partnership contains several meanings: 1) Cooperation, namely the degree of effort of one party to fulfill the wishes of another party; 2) Firmness, namely the degree of effort of one party to fulfill its own desires; 3 ) Collaboration, namely a situation where each party wants to fully fulfill the interests of all parties; 4) Compromise is a situation where each party is willing to sacrifice something so that there is a sharing of burdens and benefits (Rukmana, 2006:59).

Notoatmodjo argues that partnership is a formal cooperation between individuals, groups or organizations to achieve a certain task or goal (Notoadmodjo, 2003:30). Meanwhile, Boone et al argues that a partnership is an affiliation of two or more companies with a common goal, namely helping each other in achieving a common goal (Louis at al, 2002:21). It can be concluded that a partnership is a 
cooperation woven by two or more with a common goal, namely helping each other in achieving a common goal.

Figure 6. Partnership Dimensions

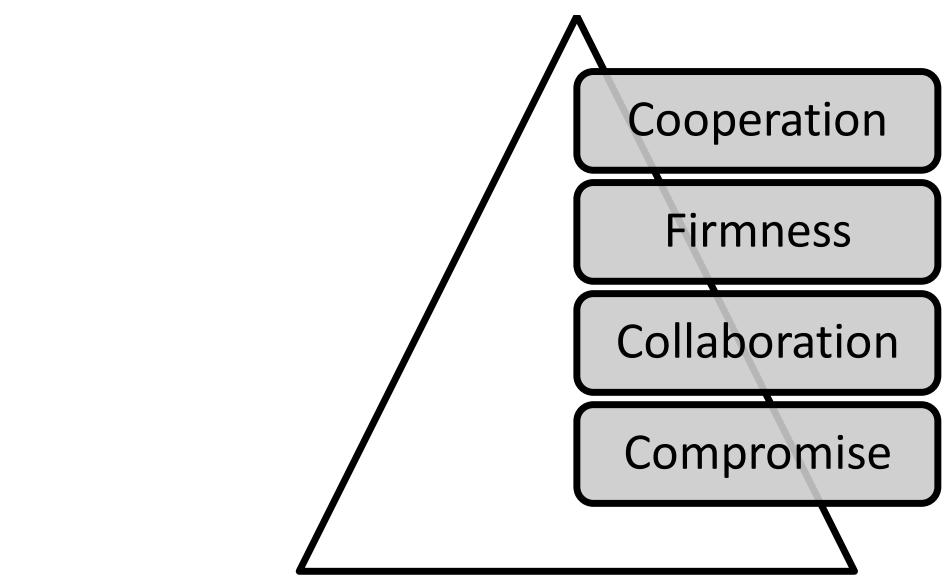

\section{D2. Partnership Principle}

The Partnership has principles in its implementation. Wibisono formulated three important principles in partnership, namely: 1) Equity; 2) Transparency; 3) Mutual benefit. The approach is neither top down nor bottom up, nor is it based on mere power, but a relationship of mutual respect and trust. To avoid antagonism, it is necessary to build mutual trust. Transparency is needed to avoid mutual suspicion between partners. Includes transparency of information management and transparency of financial management. A partnership must bring benefits to all parties involved (Wibisono, 2007:103).

Figure 7. Principles of Partnership

\section{Equity}

Transparency

Mutual Benefit 


\section{D3. Partnership Models}

In general, partnership models in the health sector are grouped into two, namely: First, the simplest partnership model is in the form of networking or building linkage. This partnership is in the form of a network only. Each partner has its own program from planning, implementation to evaluation. The network is formed because of the similarity of services or service goals and other characteristics. Second, the model is better and more solid than model I. This is because each partner has a greater responsibility than the joint program. The vision, mission, and activities in achieving the partnership goals are planned, implemented, and evaluated together (Notoadmodjo, 2003).

Figure 8. Partnership Model

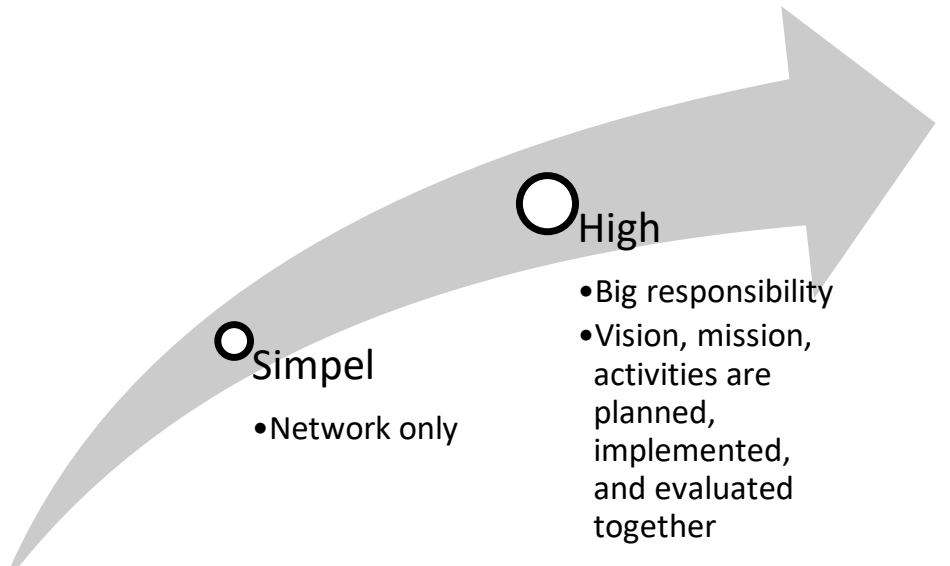

\section{D4. Partnership Supporting Factors}

In increasing the impact of partnerships so that it is better influenced by personal factors, the existence of obstacles from personal, power factors, organizational factors, obstacles in organizing, and other factors. These factors will affect satisfaction and increase the effectiveness of the commitment and the success of the activity. Dalam konteks pendidikan, kemitraan telah dikembangkan misalnya antara guru dengan orang tua (Love 2014), dan yang lebih luas adalah kemitraan antara sekolah-keluarga-masyarakat (Bryan \& Griffin, 2010). 


\section{Conclusion and Implication}

The principal's strategy describes conceptual, managerial, and social skills. Conceptual skills are tested through strategy formulation. Managerial skills are seen in strategy implementation and strategy evaluation. Social skills are very decisive in the integration of human resources to carry out the strategy. Efforts to develop partnerships between schools and the world of work (stakeholders) are the mobilization of various principal competencies to build the quality of education. The implication of this study is the importance of continuously honing conceptual, managerial, and social skills. In line with the times.

\section{Bibliography}

Akdon, D. (2006). Strategic management for educational management. Alfabeta, Bandung, 2008-2012.

Akhyak, M., Sokip, M., Soim, M., Riduwan, M., \& Hidayati, Y. (2018, July). The Role of Headmaster in Revitalization of Vocational Education. In 2018 3rd International Conference on Education, Sports, Arts and Management Engineering (ICESAME 2018). Atlantis Press.

Akib, A., Karno, E., Erdiyanti, E., Syahrul, S., Badarwan, B., \& Murniati, M. (2020, April). The use of SIMPEG-based data mining techniques in measuring employee performance in Islamic higher education. In IOP Conference Series: Materials Science and Engineering (Vol. 830, No. 3, p. 032013). IOP Publishing.

Arifin, Z. (2012). Implementasi manajemen stratejik berbasis kemitraan dalam meningkatkan mutu SMK (Studi pada SMK kelompok teknologi bidang otomotif di Kota Yogyakarta). Jurnal Administrasi Pendidikan, 14(1), 60-70.

Badarwan, B. (2020). Dinamika Sekolah Pinggiran dalam Perspektif Kepemimpinan Krisis di Kota Kendari. Shautut Tarbiyah, 24(2), 181-203.

Badarwan, B. (2021). Force Majeure Pengelolaan Pesantren di Masa Pandemi Covid-19: Studi Pada Pesantren Annur Azzubaidi, Konawe.

Bedanta, K. K. (2020). Leadership role of school headmaster. International Educational Applied Research Journal. 
Bryan, J. A., \& Griffin, D. (2010). A multidimensional study of school-family-community partnership involvement: School, school counselor, and training factors. Professional School Counseling, 14(1), 2156759X1001400108.

Boone, L. E., \& Kurtz, D. L. (2010). Pengantar Bisnis Kontemporer. Terjemahan Anwar Fadriansyah.

Danim, S. (2002). Inovasi pendidikan: dalam upaya peningkatan profesionalisme tenaga kependidikan.

Dharma, A. (1919). Manajemen supervisi: Petunjuk praktis bagi para supervisor.

Daryanto, Administrasi Pendidikan, (Jakarta: Reneka Cipta, 2010).

Departemen Agama RI. (2010). "Al-Qur'an Tajwid \& Terjemah". Bandung: CV penerbit Diponegoro.

Edward Russell-Walling, 50 Terobosan Manajamen yang perlu Anda Ketahui, ( Jakarta: Erlangga, 2008).

Eisner, A., Lumpkin, G., \& Dess, G. G. (2016). Strategic Management: Text and Cases. Mcgraw-hill EducationEurope.

Feurer, R., \& Chaharbaghi, K. (1995). Strategy development: past, present and future. Management decision.

Kartono, K. (2018). Pemimpin dan kepemimpinan. Rajawali Pers.

KH. Ahmad Mudjab Mahalli dan H. Ahmad Rodli Hasbullah. (2004). Hadis-hadis Muttafaq 'Alaih (Bagian Munakahat \& Mu'amalat). Jakarta, Kencana.

Kohtamäki, M., Kraus, S., Mäkelä, M., \& Rönkkö, M. (2012). The role of personnel commitment to strategy implementation and organisational learning within the relationship between strategic planning and company performance. International Journal of Entrepreneurial Behavior \& Research.

Kompri, M. S. (2015). Orientasi Kemandirian Kepala Sekolah. Bandung: Pustaka Pelajar, 260.

Laugi, S. (2018). Sistem Informasi berbasis Web dalam Penyelenggaran Lembaga Pendidikan. Shautut Tarbiyah, 24(1), 109-126.

Laugi, S. (2020). Use of Websites in School Management: An Effort to Build School Readiness in the Era of 4.0. Shautut Tarbiyah, 26(2), 174-191.

Love, K. R. (2014). Teacher impact on supporting the parent-teacher partnership during the middle school years. 
Mintzberg, H. (1978). Patterns in strategy formation. Management science, 24(9), 934-948.

Mukhtar, M., \& Akbar, M. (2019, December). Kiai's Leadership in Managing Human Resources. In 3rd International Conference on Education Innovation (ICEI 2019) (pp. 7982). Atlantis Press.

Mulyasa, E. (2007). Menjadi kepala sekolah profesional. Bandung: Remaja Rosdakarya.

NIM, M. R. (2019). Strategi Kepala Sekolah dalam Menjalin Kemitraan Kerja di SMK Negeri 2 Konawe Selatan (Doctoral dissertation, IAN KENDARI).

Nur, J. (2020). Kepala Sekolah Dan Kualitas Sikap pada Tugas. Shautut Tarbiyah, 24(2), 263-277.

Peraturan Menteri Pendidikan Nasional No.28 Tahun 2010 tentang Penugasan Guru Sebagai Kepala Sekolah/Madrasah.

Purwanto, M. N. (2019). Administrasi dan supervisi pendidikan.

Rukmana, N. (2006). Strategic Partnering for Educational Management. Model Manajemen Pendidikan Berbasis Kemitraan. Bandung: Alfabeta.

Sagala, S. (2013). Manajemen strategik dalam peningkatan mutu pendidikan: pembuka ruang krativitas, inovasi dan pemberdayaan potensi sekolah dalam sistem otonomi sekolah.

Sakinah, S., \& Ali, M. (2019). The Strategy of Madrasah Headmaster in Improving The Quality of Islamic Education. INTERNATIONAL JOURNAL OF CONTEMPORARY ISLAMIC EDUCATION, 1(1), 103-124.

Sholekah, F. F., \& Mahmudah, F. N. (2020). THE MANAGEMENT STRATEGY OF HEADMASTER IN EFFORTS TO INCREASE SELF AWARENESS OF SCHOOL RESIDENTS OF THE IMPORTANCE ENVIRONMENT. Educational Administration Research and Review, 4(1), 6167.

Shuttleworth, M. (2009). What is a literature review. Retrieved June, 13, 2012.

Singh, R. K., Garg, S. K., \& Deshmukh, S. G. (2008). Strategy development by SMEs for competitiveness: a review. Benchmarking: An international journal. 
Soekidjo, N. (2003). Pendidikan Kesehatan dan Perilaku Kesehatan. Jakarta: Penerbit Rineka Cipta, 24-28.

Suliah, E. H., \& Arafat, Y. (2019). Headmaster's Strategy to Maximizes Using Infrastructure and Teachers' Role to Improve Learning Quality in Elementary School. International Journal of Scientific and Technology Research, $8(5), 120-23$.

Suryosubroto, B. (2004). Manajemen pendidikan di sekolah. Rineka Cipta.

Syahrul, S. (2015). Mengelola Perguruan Tinggi dalam Iklim Ketidakpastian (Memahami Dinamika Perencanaan Strategis di STAIN Sultan Qaimuddin Kendari). Al-Izzah: Jurnal Hasil-Hasil Penelitian, 10(1), 143-160.

Syahrul, S. (2015). Kepemimpinan dan Inovasi Lembaga Pendidikan (Pengalaman Pondok Gontor VII Putra Sulawesi Tenggara). Al-TA'DIB: Jurnal Kajian Ilmu Kependidikan, 8(1), 82-100.

Syahrul, S., Karno, E., \& Badarwan, B. (2017). Social Responsibility of University: Bridging Moslim Reality in Strategic Plan of IAIN Kendari, Southeast Celebes, Indonesia.

Syahrul, S. (2019). Invisible Competition: Pergulatan Membangun Keunggulan dalam Bingkai Tradisi di Pesantren Annur Azzubaidi, Konawe, Sulawesi Tenggara.

Syahrul, S., Alim, N., Pairin, P., \& Nur, J. (2019). Utilization of management information systems in managerial supervision at IAIN Kendari. International Journal of Recent Technology and Engineering (TM), 8(1C2), 392-392.

Tobari, M. K., \& Asvio, N. (2018). The Strategy of Headmaster On Upgrading Educational Quality In Asean Economic Community (AEC) Era. International Journal of Scientific \& Technology Research Volume, 7.

Utami, S. (2010). Kemitraan Sekolah Menengah Kejuruan dengan Dunia Usaha dan Dunia Industri melalui Praktik Kerja Industri: Studi Multisitus di SMK Negeri 3 Malang dan SMK Cor Jesu Malang.(Tesis). DISERTASI dan TESIS Program Pascasarjana UM.

Wahjosumidjo. (1999). Kepemimpinan kepala sekolah: tinjauan teoritik dan permasalahannya. Rajagrafindo Persada (Rajawali Pers). 
Wahyudi, D. R. (2009). Kepemimpinan Kepala Sekolah Dalam Organisasi Pembelajar (Learning Organization). Alfabeta: Bandung.

Wahyu, S. (2020). STRATEGI PENINGKATAN MUTU TERPADU DI MADRASAH BERTARAF INTERNASIONAL (MBI) AMANATUL UMMAH PACET-MOJOKERTO (Doctoral dissertation, Institut Pesantren KH. Abdul Chalim).

Winardi. (2012). Dasar-Dasar Manajamen. Mandar Maju, Bandung.

Wong, A. Y., \& Daud, K. (2017). Headmaster Technology Leadership in Malaysia Elementary Schools. Journal of Education and Learning, 11(2), 154-164.

Yalianto, Y., \& Sutrisno, B. (2015). Pengelolaan Kerjasama Sekolah dengan Dunia Usaha/Dunia Industri (Studi Situs SMK Negeri 2 Kendal). Jurnal Pendidikan Ilmu Sosial, 24(1), 19-37.

Yulmawati, Y. (2017). Strategi Kepemimpinan Kepala Sekolah Dalam Meningkatkan Mutu Pendidikan SD Negeri 03 Sungayang. JMKSP (Jurnal Manajemen, Kepemimpinan, dan Supervisi Pendidikan), 1(2), 109-121.

Yusuf, W. (2007). Membedah konsep dan aplikasi CSR. Gresik: Faseho Publishing. 